\title{
Radionuclides in south Indian seafoods: A special focus on major contributing species
}

\author{
S.G. Wesley and M.F. Khan* \\ Department of Zoology and Research Centre, Scott Christian College (Autonomous), \\ Nagercoil - 629 003, Kanniyakumari District, Tamil Nadu, India
}

\begin{abstract}
Concentrations of natural radionuclides ${ }^{238} \mathrm{U},{ }^{208} \mathrm{Tl}\left({ }^{232} \mathrm{Th}\right),{ }^{226} \mathrm{Ra},{ }^{210} \mathrm{Po},{ }^{210} \mathrm{~Pb}$ and ${ }^{40} \mathrm{~K}$, and fallout ${ }^{137} \mathrm{Cs}$ were determined in pelagic and demersal fishes which are of economic importance. Pelagic fishes concentrated more radionuclides in the muscle tissue when compared to benthic species. Similarly, teleosts registered more activity than elasmobranchs. Based on the activity levels in muscle, the intake, effective dose and lifetime risks to humans were estimated. The internal radiation doses received by fishes and human beings seem to be mainly due to ${ }^{210} \mathrm{Po}$ and ${ }^{40} \mathrm{~K}$. The fishes were found to be safe for consumption.
\end{abstract}

\section{INTRODUCTION}

Fish production is very significant for global food trade and food security, as fish provides more than $15 \%$ of total animal protein supplies. About $38 \%$ of world fish production enters international trade and around $50 \%$ (in value terms) of this trade originates in developing countries. Recent growth in the demand for seafood throughout the world has led to a considerable increase in interest in the safety of marine organisms as food sources [1]. In order to determine seafood safety, many countries have carried out research programmes on various kinds of pollutants in marine organisms [2]. Naturally occurring U and Th series radionuclides, singly occurring ${ }^{40} \mathrm{~K}$ and fallout ${ }^{137} \mathrm{Cs}$ in marine ecosystem have attracted special interest due to their chemical and radioactive properties. The naturally occurring radionuclides, ${ }^{238} \mathrm{U},{ }^{208} \mathrm{Tl},{ }^{226} \mathrm{Ra},{ }^{210} \mathrm{Po},{ }^{210} \mathrm{~Pb}$ and ${ }^{40} \mathrm{~K}$, and fallout ${ }^{137} \mathrm{Cs}$ are important contributors to radiation dose received by human beings via seafood consumption, because of their high accumulation rates in the edible parts (especially ${ }^{210} \mathrm{Po}$ ) of marine organism [3, 4]. Data pertaining to the above-mentioned radionuclides remain scanty in the southern coastal regions of India, one of the high background radiation areas (HBRA) of the world. Among the seafoods, fishes are the most important species, representing more than 200 edible species alone from the southern coast of India [5]. No guideline values have been calculated for radionuclide levels in Indian seafoods till date. Based on the above scenario, the present study was carried out to find out the distribution of natural radionuclides in the economically important edible pelagic and demersal fish species of the southeastern coast of India and to estimate the radiation dose to humans in terms of seafood safety.

\section{MATERIALS AND METHODS}

\subsection{Collection of samples}

Thirty-four species of edible pelagic and demersal fishes were collected at the major fish-landing centres (Chinnamuttom and Idinthakarai) and were also caught by trawling at 10 nautical miles offshore between Kanniyakumari and Uvari (Fig. 1). Samples were collected during January 2009 to March 


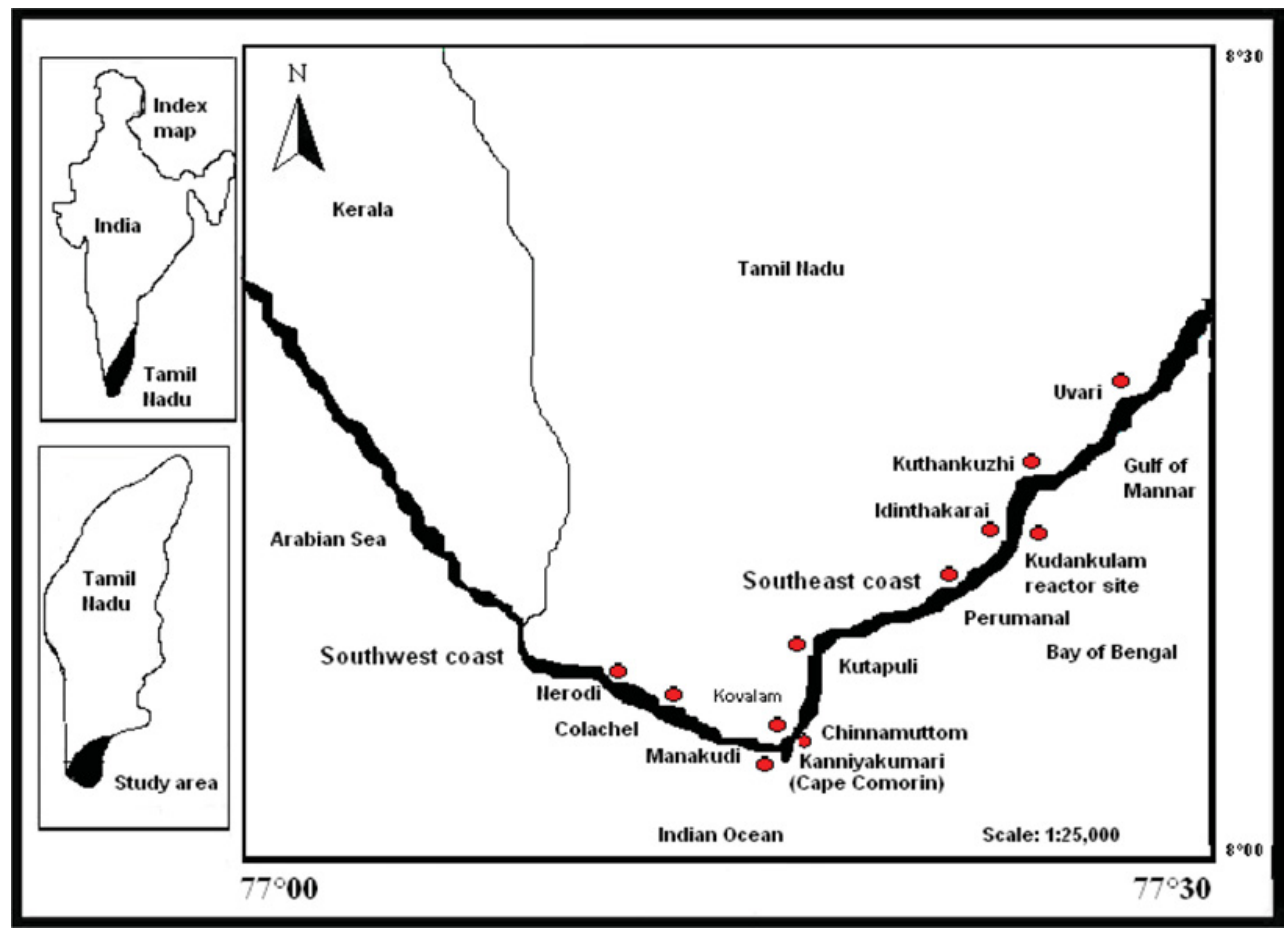

Figure 1. Map showing the study area.

2010. The collected samples were brought to the laboratory and washed thoroughly with tap water to remove debris, sand and silt. The fishes were identified and categorized according to their ecological characteristics and distribution using Fishbase online (www.fishbase.org). Mostly, similar-sized fish in each species were taken into consideration and analysed. Seawater $(100 \mathrm{~L})$ samples were collected using a PVC water sampler inshore as well as offshore (depth range of 5-40 m) from the fish sampled area to derive the biological concentration factor $(\mathrm{BCF})$.

\subsection{Radionuclide determination}

Five litres of seawater, after the $\mathrm{pH}$ was adjusted to 1 with $\mathrm{HCl}$, was evaporated and reduced to $500 \mathrm{ml}$. The water was then compactly packed in $500 \mathrm{ml}$ high quality polythene bottles, sealed and kept undisturbed for 1 month (for the daughter radionuclides of the U-Th series) for the determination of ${ }^{40} \mathrm{~K},{ }^{238} \mathrm{U},{ }^{208} \mathrm{Tl}\left({ }^{232} \mathrm{Th}\right)$, and ${ }^{226} \mathrm{Ra} .{ }^{137} \mathrm{Cs}$ was pre-concentrated with ammonium molybdophosphate (AMP) from 301 of seawater [6]. The samples were subjected to low-level hyper pure germanium gamma spectrometry $(\mathrm{HpGe})$ for $50,000 \mathrm{~s}$. On the other hand, ${ }^{210} \mathrm{Po}$ in seawater was determined by pre-concentration using $\mathrm{Fe}(\mathrm{OH})_{3}$ followed by silver plating [7]. The solution, after plating, was stored for 6 months in glass bottles to allow the ingrowth of ${ }^{210} \mathrm{Po}$ from its grandparent, ${ }^{210} \mathrm{~Pb}$. Subsequent determination of the ingrown ${ }^{210} \mathrm{Po}$ was carried out as described above [8].

In case of fishes, the samples were dissected out to remove the edible soft tissue from the hard parts. Muscle tissue was pooled from all the specimens representing each species, weighed and dried in an oven at $80-90^{\circ} \mathrm{C}$. The dried samples were then charred in a silica crucible at low flame and then made to ash in a muffle furnace at $450^{\circ} \mathrm{C}$; and $10-15 \mathrm{~g}$ of the homogenized ash was filled in a glass vial and subjected to gamma spectrometry. The gamma activity measurement was carried out at the Environmental Survey Laboratory, Health Physics Division, Bhabha Atomic Research Centre, 
Kudankulam. The detector has a relative efficiency of $110 \%$ and a resolution of $2.3 \mathrm{keV}$ (FWHM) for the peak of $1332 \mathrm{keV}$ of ${ }^{60} \mathrm{Co}$ [9]. The detector is coupled to a 4096-multichannel computer analyser (MCA). To reduce the $\gamma$-ray background the detector is shielded by a cylindrical, 5.08-cm thick Pb shield with a fixed bottom and a moving cover. The peak areas $(\mathrm{keV})$ in the gamma spectrum were 661.7 for ${ }^{137} \mathrm{Cs}, 1460.8$ for ${ }^{40} \mathrm{~K}, 510.6$, 583 and 2614.4 for ${ }^{208} \mathrm{Tl}\left({ }^{232} \mathrm{Th}\right), 609.3$ and 1120.3 for ${ }^{238} \mathrm{U}$ and 1764.5 for ${ }^{226} \mathrm{Ra}$. Internal quality was checked using the reference material, IAEA 315 , RGhK-1, RGhTh-1 and RGhU-1 within \pm 1 SD of the reference value. The accuracy and precision of the radiochemical determination were estimated to be less than $5 \%$.

Meanwhile, 5-10g of each tissue sample was wet-digested for ${ }^{210} \mathrm{Po}$ determination using a three-to-four-step digestion procedure using a $\mathrm{HNO}_{3}: \mathrm{H}_{2} \mathrm{O}_{2}: \mathrm{HCl}$ mixture along with the addition of $0.4 \mathrm{~Bq}^{208} \mathrm{Po}$ tracer [8]. After complete digestion, nearing dryness, concentrated $\mathrm{HCl}$ was added to remove $\mathrm{HNO}_{3}$, after which ${ }^{210} \mathrm{Po}$ was plated onto a polished silver disc and counted for $\alpha$ activity by using an alpha counter for $6000 \mathrm{sec}$ (Nucleonix-make RC605A, efficiency 35\% using ${ }^{241} \mathrm{Am}$ standard, minimum detectable limit $0.2 \mathrm{~Bq}) .{ }^{210} \mathrm{~Pb}$ analysis was performed as explained above. The ${ }^{210} \mathrm{Po}$ activity corresponds to that of its grandparent, ${ }^{210} \mathrm{~Pb}$, in the sample. The recovery of polonium was ensured by doing a second plating to completely remove $(100 \%)$ the ${ }^{210} \mathrm{Po}$ along with the tracer. Tracer addition was done 1 day before the second ${ }^{210}$ Po deposition (after 6 months) to ensure isotopic exchange.

Radionuclide activities in surface water and fishes are given in $\mathrm{Bq} \cdot \mathrm{m}^{-3}$ and $\mathrm{Bq} \cdot \mathrm{kg}^{-1}$ wet weight (ww), respectively. The results are reported as the mean of values measured for the individual organisms and $\pm 1 \sigma$ standard deviation (SD) for each group of data.

\section{RESULTS AND DISCUSSION}

In general, the concentrations of uranium and radium isotopes were lower compared to ${ }^{210} \mathrm{~Pb}$ and ${ }^{210} \mathrm{Po}$ (Table 1). Among the naturally occurring alpha emitters, ${ }^{210} \mathrm{Po}$ displayed concentrations ranging from 2.6 to $99.9 \mathrm{~Bq} \cdot \mathrm{kg}^{-1}$ and was present in fish muscle in concentrations higher than other radionuclides. Among naturally occurring gamma-emitting radionuclides, radioactive potassium $\left({ }^{40} \mathrm{~K}\right)$ displayed higher concentrations, ranging from 33.9 to $128.6 \mathrm{~Bq} \cdot \mathrm{kg}^{-1}$.

Among fish species, benthic species displayed lesser natural radionuclide concentration (except for ${ }^{210} \mathrm{~Pb}$ ) compared to bony fishes (teleosts). Pelagic species showed higher ${ }^{210} \mathrm{Po}$ and ${ }^{40} \mathrm{~K}$ activity when compared to benthic species. The pelagic species was headed by the Indian oil sardine, Sardinella longiceps, a specific planktivorous pelagic fish whose eggs are released in the pelagic zone and whose larvae, fry and juveniles develop there. Moreover, the period of pelagic life as adults or at early stages and their feeding on plankton are significant. The role of plankton in this process is also significant because it is the primary ${ }^{210} \mathrm{Po}$ uptake source for fishes [10]. Meanwhile, fish feeding on benthic organisms showed higher ${ }^{210} \mathrm{~Pb}$ and ${ }^{226} \mathrm{Ra}$ activity. The concentration registered for ${ }^{208} \mathrm{Tl}\left({ }^{232} \mathrm{Th}\right)$ in fishes was found higher than that of ${ }^{238} \mathrm{U}$. The accumulation pattern was found to be more or less similar in most of the species. ${ }^{137} \mathrm{Cs}$, on the other hand, was found to be more in concentration in the predatory fishes.

${ }^{137} \mathrm{Cs}$ concentrations were generally in the range of 0.06 to $0.34 \mathrm{~Bq} \cdot \mathrm{kg}^{-1}$. The migratory yellow fin tuna Thunnus albacares displayed the highest activity. The level of ${ }^{137} \mathrm{Cs}$ in the present study was similar to the values reported before for other marine fish [11-14]. In terms of the absorbed radiation dose, and taking into account the concentrations measured, the naturally occurring radionuclides, especially ${ }^{40} \mathrm{~K},{ }^{226} \mathrm{Ra}$ and ${ }^{210} \mathrm{Po}$, are the ones that contribute more to the radiation doses to the fish as well as to human consumers of seafood. The concentrations of radionuclides in fish muscle varied among species even when they were caught in the same fishing area, suggesting differential bioaccumulation of radionuclides. Furthermore, in several species, including sardines, mackerels and scads concentrations of ${ }^{210} \mathrm{Po}$ and ${ }^{210} \mathrm{~Pb}$ varied substantially in internal organs [7]. The lowest concentrations of these radionuclides were generally recorded in the muscle and bone, whereas the highest concentrations was 
Table 1. Radionuclide levels in different fishes.

\begin{tabular}{|c|c|c|c|c|c|c|c|c|}
\hline & \multirow[t]{2}{*}{ Species } & \multicolumn{7}{|c|}{ Radionuclide concentration $\left(\mathrm{Bq} \cdot \mathrm{kg}^{-1}\right.$ wet weight $)$} \\
\hline & & ${ }^{137} \mathrm{Cs}$ & ${ }^{40} \mathrm{~K}$ & ${ }^{238} \mathrm{U}$ & ${ }^{208} \mathrm{Tl}\left({ }^{232} \mathrm{Th}\right)$ & ${ }^{226} \mathrm{Ra}$ & ${ }^{210} \mathrm{~Pb}$ & ${ }^{210} \mathrm{Po}$ \\
\hline & Pelagic fishes & & & & & & & \\
\hline 1. & $\begin{array}{l}\text { Indian Oil Sardine, } \\
\quad \text { Sardinella longiceps }\end{array}$ & 0.12 & 128.6 & 0.29 & 1.2 & 0.45 & 12.5 & 99.9 \\
\hline 2. & $\begin{array}{l}\text { White Sardinella, } \\
\text { Sardinella albella }\end{array}$ & 0.14 & 112.2 & 0.39 & 1.1 & 0.32 & 16.9 & 74.2 \\
\hline 3. & $\begin{array}{l}\text { Fringiscale Sardine, } \\
\text { Sardinella fimbriata }\end{array}$ & 0.16 & 99.8 & 0.45 & 0.98 & 0.63 & 10.9 & 62.3 \\
\hline 4. & $\begin{array}{l}\text { Wolf herring, } \\
\text { Chirocentrus dorab }\end{array}$ & 0.15 & 76.5 & 0.24 & 0.97 & 0.66 & 5.6 & 42.3 \\
\hline 5. & $\begin{array}{l}\text { Hilsa shad, } \\
\text { Hilsa ilisha }\end{array}$ & 0.2 & 81.2 & 0.21 & 1.4 & 0.52 & 9.9 & 39.9 \\
\hline 6. & $\begin{array}{l}\text { Commerson's anchovy, } \\
\text { Stolephorus commersonii }\end{array}$ & 0.19 & 88.3 & 0.22 & 0.97 & 1.1 & 14.5 & 52.6 \\
\hline 7. & $\begin{array}{l}\text { Devis' anchovy, } \\
\text { Encrasicholina devisi }\end{array}$ & 0.21 & 72.3 & 0.31 & 0.85 & 0.7 & 15.2 & 44.9 \\
\hline 8. & $\begin{array}{l}\text { Goldspotted gredanier anchovy, } \\
\text { Coilia dussumieri }\end{array}$ & 0.16 & 63.5 & 0.25 & 1 & 0.41 & 9.8 & 62.3 \\
\hline 9. & $\begin{array}{l}\text { Savalai hairtail, } \\
\quad \text { Lepturacanthus savala }\end{array}$ & 0.09 & 77.6 & 0.34 & 1.1 & 0.39 & 10.8 & 23.6 \\
\hline 10. & $\begin{array}{l}\text { Torpedo scad, } \\
\text { Megalaspis cordyla }\end{array}$ & 0.11 & 56.6 & 0.65 & 1.3 & 0.64 & 8.8 & 20.6 \\
\hline 11. & $\begin{array}{l}\text { Indian scad, } \\
\quad \text { Decapterus russelli }\end{array}$ & 0.13 & 58.6 & 0.29 & 1.23 & 0.58 & 7.4 & 21.2 \\
\hline 12. & $\begin{array}{l}\text { Malabar trevally, } \\
\text { Carangoids malabaricus }\end{array}$ & 0.12 & 66.9 & 0.28 & 0.88 & 0.82 & 9.4 & 19.8 \\
\hline 13. & $\begin{array}{l}\text { Razorbelly scad, } \\
\text { Alepes kleinii }\end{array}$ & 0.1 & 48.9 & 0.37 & 0.79 & 0.65 & 14.5 & 81.5 \\
\hline 14. & $\begin{array}{l}\text { Indian mackerel, } \\
\text { Rastrelliger kanagurta }\end{array}$ & 0.22 & 97.9 & 0.38 & 1.31 & 1.2 & 12.2 & 88.9 \\
\hline 15. & $\begin{array}{l}\text { Kawakawa, } \\
\text { Euthynnus affinis }\end{array}$ & 0.31 & 88.7 & 0.41 & 1.22 & 0.49 & 5.9 & 15.4 \\
\hline 16. & $\begin{array}{l}\text { Yellowfin tuna, } \\
\text { Thunnus albacares }\end{array}$ & 0.34 & 68.8 & 0.45 & 1.24 & 0.55 & 6.6 & 12.9 \\
\hline 17. & $\begin{array}{c}\text { Narrow-barred Spanish mackerel, } \\
\text { Scombereomorus commerson }\end{array}$ & 0.25 & 77.6 & 0.36 & 1.3 & 0.67 & 7.1 & 19.5 \\
\hline 18. & $\begin{array}{l}\text { Indo-pacific king mackerel, } \\
\text { Scombereomorus guttatus }\end{array}$ & 0.26 & 84.2 & 0.46 & 1.5 & 0.78 & 6.2 & 29.8 \\
\hline 19. & $\begin{array}{l}\text { Silver pomfret, } \\
\text { Pampus argenteus }\end{array}$ & 0.14 & 43.6 & 0.23 & 1.95 & 0.88 & 5.5 & 13.6 \\
\hline 20. & $\begin{array}{l}\text { Great barracuda, } \\
\text { Sphyraena barracuda }\end{array}$ & 0.26 & 55.9 & 0.29 & 0.96 & 1 & 11.5 & 41.2 \\
\hline
\end{tabular}


Table 1. Continued.

\begin{tabular}{|c|c|c|c|c|c|c|c|c|}
\hline & \multirow[t]{2}{*}{ Species } & \multicolumn{7}{|c|}{ Radionuclide concentration $\left(\mathrm{Bq} \cdot \mathrm{kg}^{-1}\right.$ wet weight) } \\
\hline & & ${ }^{137} \mathrm{Cs}$ & ${ }^{40} \mathrm{~K}$ & ${ }^{238} \mathrm{U}$ & ${ }^{208} \mathrm{Tl}\left({ }^{232} \mathrm{Th}\right)$ & ${ }^{226} \mathrm{Ra}$ & ${ }^{210} \mathrm{~Pb}$ & ${ }^{210} \mathrm{Po}$ \\
\hline & Demersal fishes & & & & & & & \\
\hline 21. & $\begin{array}{l}\text { Milk shark, } \\
\text { Carcarhinus sorrah }\end{array}$ & 0.21 & 36.9 & 0.25 & 0.85 & 0.9 & 5.4 & 12.5 \\
\hline 22. & $\begin{array}{l}\text { Greasy grouper, } \\
\text { Epinephelus tauvina }\end{array}$ & 0.19 & 35.5 & 0.28 & 0.96 & 0.25 & 5.6 & 10.9 \\
\hline 23. & $\begin{array}{l}\text { Spinycheek grouper, } \\
\text { Epinephelus diacanthus }\end{array}$ & 0.23 & 39.6 & 0.33 & 1.26 & 0.71 & 6.6 & 12.6 \\
\hline 24. & $\begin{array}{l}\text { Sole fish, } \\
\text { Cynoglossus macrostomas }\end{array}$ & 0.07 & 42.5 & 0.61 & 1.35 & 0.48 & 15.6 & 2.6 \\
\hline 25. & $\begin{array}{l}\text { Silver sillago, } \\
\quad \text { Sillago sihama }\end{array}$ & 0.06 & 53.6 & 0.24 & 1.39 & 0.51 & 12.6 & 5.9 \\
\hline 26. & $\begin{array}{l}\text { Striped ponyfish, } \\
\quad \text { Leiognathus fasciatus }\end{array}$ & 0.08 & 45.5 & 0.44 & 1.55 & 0.52 & 6.6 & 7.8 \\
\hline 27. & $\begin{array}{l}\text { Dussumier's ponyfish, } \\
\text { Leiognathus dussumieri }\end{array}$ & 0.08 & 49.5 & 0.56 & 1.83 & 0.6 & 7.2 & 7.9 \\
\hline 28. & $\begin{array}{l}\text { Lesser tigertooth croaker, } \\
\text { Otolithes cuvieri }\end{array}$ & 0.18 & 72.5 & 0.66 & 0.92 & 0.38 & 11.2 & 25.6 \\
\hline 29. & $\begin{array}{l}\text { Blotched croaker, } \\
\text { Nibea maculata }\end{array}$ & 0.17 & 63.3 & 0.25 & 1.25 & 0.44 & 10.9 & 32.5 \\
\hline 30. & $\begin{array}{l}\text { Moontail bullseye, } \\
\text { Priacanthus hamrur }\end{array}$ & 0.15 & 66.3 & 0.22 & 1.6 & 0.65 & 12.6 & 26.6 \\
\hline 31. & $\begin{array}{l}\text { Finstripe goatfish, } \\
\text { Upeneus taeniopterus }\end{array}$ & 0.06 & 54.4 & 0.61 & 0.99 & 0.45 & 15.9 & 11.5 \\
\hline 32. & $\begin{array}{l}\text { Lizard fish, } \\
\text { Saurida tumbil }\end{array}$ & 0.07 & 33.9 & 0.57 & 1.12 & 0.98 & 18.7 & 4.9 \\
\hline 33. & $\begin{array}{l}\text { False trevally, } \\
\text { Lactarius lactarius }\end{array}$ & 0.08 & 35.9 & 0.58 & 1.18 & 0.87 & 12.9 & 8.8 \\
\hline 34. & $\begin{array}{l}\text { Convict surgeonfish, } \\
\text { Acanthurus triostegus }\end{array}$ & 0.16 & 44.9 & 0.49 & 1.17 & 0.57 & 13.5 & 15.4 \\
\hline
\end{tabular}

more consistently noted in liver. It is interesting to note the elevated ${ }^{210}$ Po concentrations in fish liver and gonad, which are consumed in many countries [15].

Among naturally occurring radionuclides, the contribution of ${ }^{210} \mathrm{Po}$ was always higher than that of the other nuclides of the uranium series, namely ${ }^{238} \mathrm{U},{ }^{226} \mathrm{Ra}$ and ${ }^{210} \mathrm{~Pb}$. In general, in the muscle tissue, ${ }^{210}$ Po concentrations were $10-100$ times higher than those of ${ }^{226} \mathrm{Ra}$, which in turn was about 10 times higher than ${ }^{238} \mathrm{U}$. As observed in the upper pelagic domain and in coastal waters, plankton feeding groups displayed higher ${ }^{210}$ Po concentrations. So far, all the experimental evidence accumulated indicates that ${ }^{210} \mathrm{Po}$ intake by marine organisms mainly takes place via food ingestion and it is not absorbed directly from seawater in significant amounts [16-18]. The level of radionuclides in seawater was shown in Fig. 2. Furthermore, it has been demonstrated that, in cells, polonium binds easily to amino acids and proteins, which facilitates ${ }^{210}$ Po absorption through a predator's gut and accumulation in the internal organs [19]. The estimated biological concentration factor (BCF) was depicted in Fig. 3.

It has been shown that in all oceanic ecological domains there are organisms with particularly high concentrations of ${ }^{210} \mathrm{Po}$, and these organisms or some of their organs may receive high radiation doses 


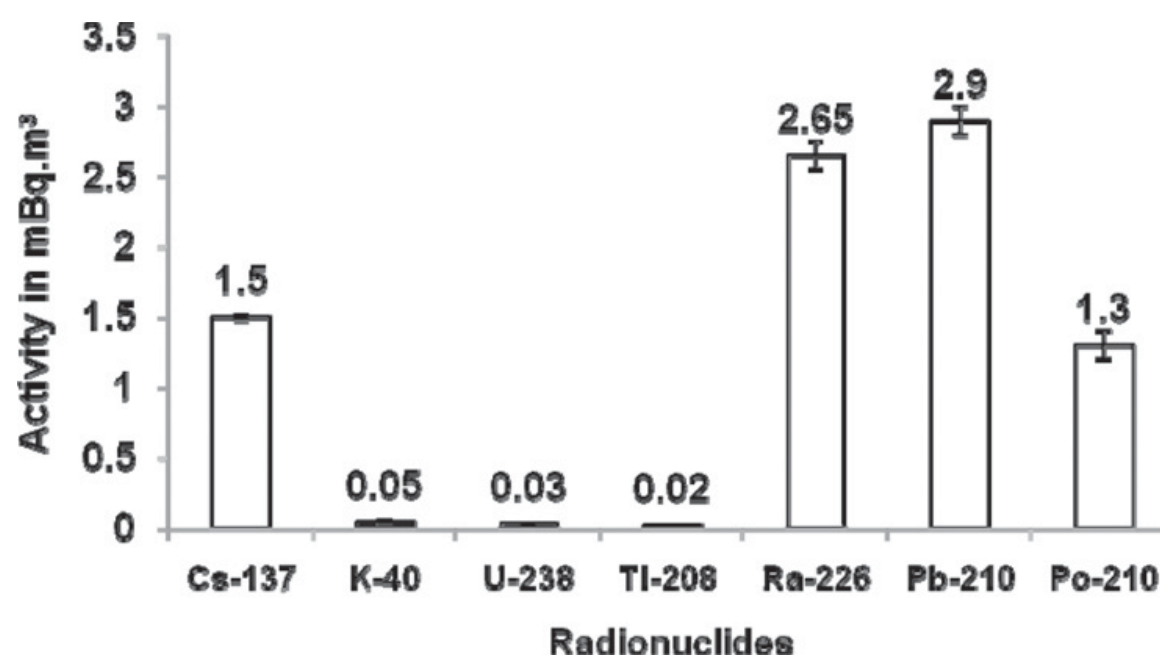

Figure 2. Radionuclide activity levels in seawater.

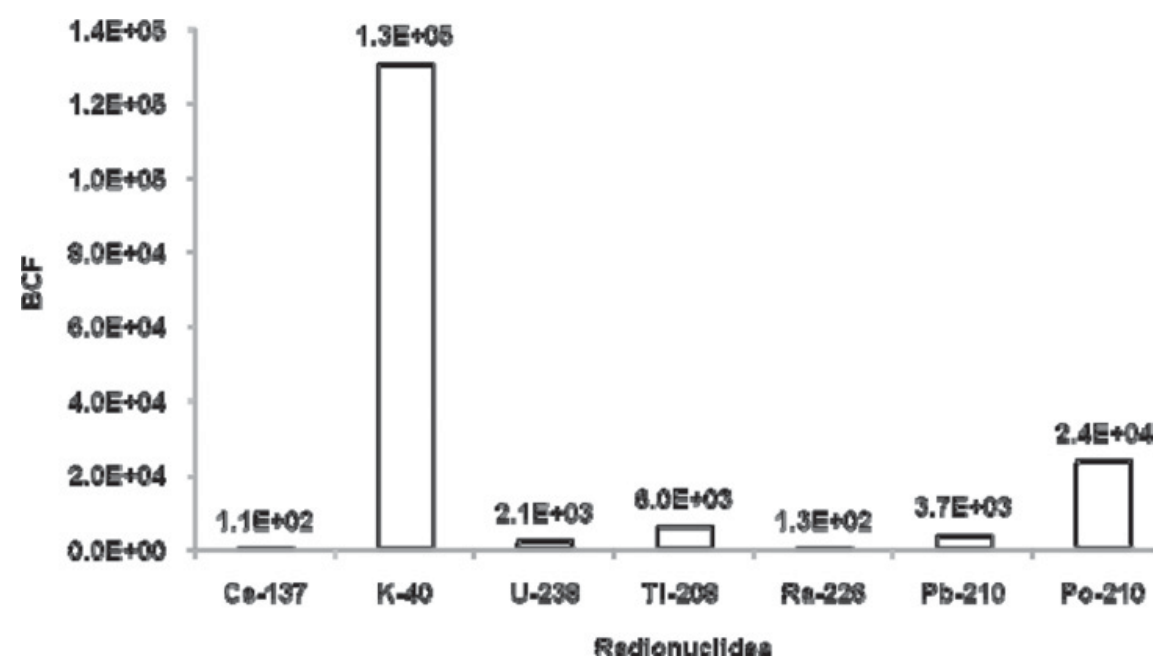

Figure 3. Radionuclide BCF calculated for fishes.

from internally accumulated ${ }^{210} \mathrm{Po}[11,20,21]$. Absorbed radiation doses have been estimated for fishes, and the internal dose rate for fishes were estimated to be in the range of $1.26 \times 10^{-5}$ to $0.12 \mu \mathrm{Gy} \cdot \mathrm{h}^{-1}$ (Fig. 4). Pelagic fishes are the most exposed compared to other fishes. This observation is concordant with the finding of Carvalho and Oliveira [12]. It has also been reported and found that the radiation dose received from internally accumulated radionuclides will be higher than the dose from external radionuclides in seawater and seafloor sediments [22]. Among the internal emitters, ${ }^{40} \mathrm{~K}$ and ${ }^{210}$ Po were the main contributors to the dose. Radiation doses due to internally accumulated artificial radionuclides contribute very little, about $1 \%$, to the dose from naturally occurring radionuclides [12].

The annual committed effective dose for individuals as a result of radionuclide intake was calculated using dose conversion factors $\left(\mu \mathrm{Sv} \cdot \mathrm{Bq}^{-1}\right)$ for adults recommended by IAEA [15]. The dose was calculated as given in Khan and Wesley [22]. For the human consumers of fish, the presence of natural anthropogenic radionuclides in fish and their absorption through the diet certainly adds a radiation dose 


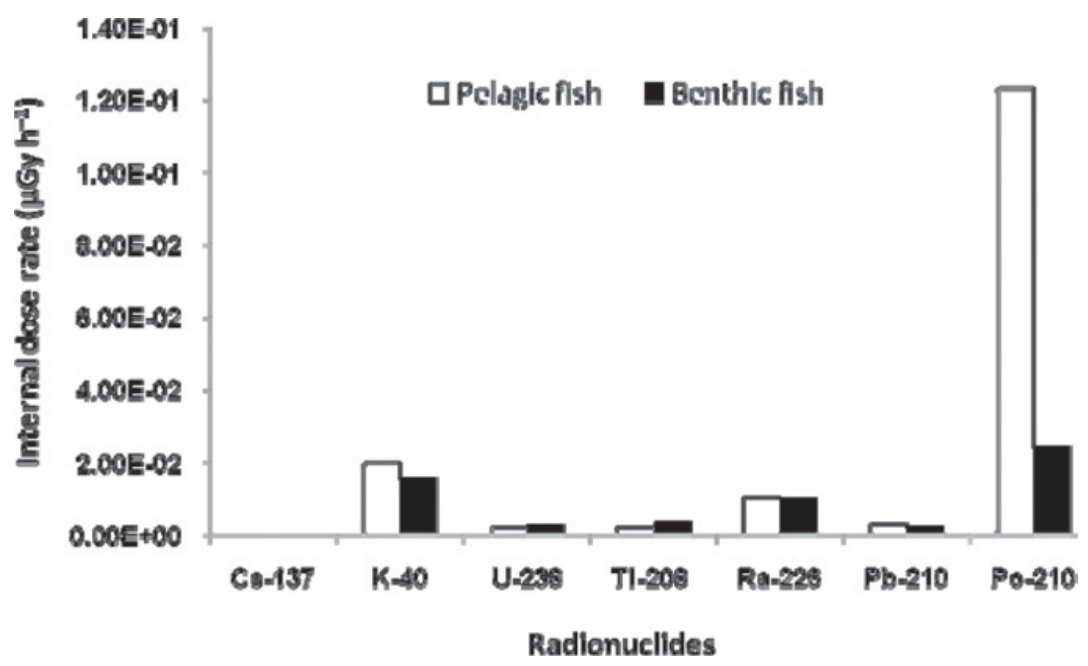

Figure 4. Internal dose rate calculated for fishes.

Table 2. Dose parameters calculated for public.

\begin{tabular}{lcccc}
\hline Radionuclides & $\begin{array}{c}\text { Average activity } \\
\left(\mathrm{Bq} \cdot \mathrm{kg}^{-1}\right)\end{array}$ & $\begin{array}{c}\text { Daily intake } \\
\left(\mathrm{Bq}^{-1}\right)\end{array}$ & $\begin{array}{c}\text { Annual intake } \\
\left(\mathrm{Bq} \cdot \mathrm{y}^{-1}\right)\end{array}$ & $\begin{array}{c}\mathrm{CED} \\
\left(\mu \mathrm{Sv} \cdot \mathrm{y}^{-1}\right)\end{array}$ \\
\hline $\mathrm{Cs}-137$ & 0.16 & 0.008 & 2.92 & 0.04 \\
$\mathrm{~K}-40$ & 65.4 & 3.27 & 1193.55 & 7.40 \\
$\mathrm{U}-238$ & 0.34 & 0.017 & 6.205 & 0.03 \\
$\mathrm{Tl}-208$ & 1.2 & 0.06 & 21.9 & 5.04 \\
$\mathrm{Ra}-226$ & 0.64 & 0.032 & 11.68 & 3.27 \\
$\mathrm{~Pb}-210$ & 10.7 & 0.535 & 195.275 & 134.74 \\
Po-210 & 30.9 & 1.545 & 563.925 & 676.71 \\
\hline
\end{tabular}

Table 3. Risk parameters calculated for public.

\begin{tabular}{lcccc}
\hline Radionuclides & Risk coefficient & Annual intake $\left(\mathrm{Bq} \cdot \mathrm{y}^{-1}\right)$ & Risk $\left(\mathrm{y}^{-1}\right)$ & Life time risk \\
\hline $\mathrm{Cs}-137$ & $5.71 \mathrm{E}-10$ & 2.92 & $1.67 \mathrm{E}-09$ & $1.03 \mathrm{E}-07$ \\
$\mathrm{~K}-40$ & $2.28 \mathrm{E}-10$ & 1193.55 & $2.72 \mathrm{E}-07$ & $1.69 \mathrm{E}-05$ \\
$\mathrm{U}-238$ & $7.31 \mathrm{E}-10$ & 6.21 & $4.54 \mathrm{E}-09$ & $2.81 \mathrm{E}-07$ \\
$\mathrm{Tl}-208$ & $5.61 \mathrm{E}-10$ & 21.90 & $1.23 \mathrm{E}-08$ & $7.62 \mathrm{E}-07$ \\
$\mathrm{Ra}-226$ & $5.26 \mathrm{E}-09$ & 11.68 & $6.14 \mathrm{E}-08$ & $3.81 \mathrm{E}-06$ \\
$\mathrm{~Pb}-210$ & $1.48 \mathrm{E}-08$ & 195.28 & $2.89 \mathrm{E}-06$ & $1.79 \mathrm{E}-04$ \\
$\mathrm{Po}-210$ & $5.88 \mathrm{E}-09$ & 563.93 & $3.32 \mathrm{E}-06$ & $2.06 \mathrm{E}-04$ \\
\hline
\end{tabular}

to consumers. In an early assessment of ${ }^{210} \mathrm{Po}$ and ${ }^{210} \mathrm{~Pb}$ contributions to the radiation dose received by human consumers through the ingestion of food and water and air inhalation, Carvalho [11] had concluded that ingestion is the main exposure pathway for humans, and that the dose from marine products would be higher. The calculated dose and risk parameters are shown in Tables 2 and 3. In the present study, the summed committed effective dose for adults was calculated to be $827.2 \mu \mathrm{Sv} \cdot \mathrm{y}^{-1}$. The life time risk due to the intake of radionuclides was determined as per USEPA [23] and Khan et al. [24]. It was calculated to be $4.07 \times 10^{-4}$. This value is negligible compared to the total risk $\left(6 \times 10^{-3}\right.$ i.e., 
$0.6 \%$ ) involved from average global natural radiation dose of $2.4 \mathrm{mSv} \mathrm{y}^{-1}$ to humans. The estimated values are also significantly less than the ICRP cancer risk factor of $2.5 \times 10^{-3}$ based on the additional annual dose limit of $1 \mathrm{mSv}$ for the general public, which yields an annual mortality probability of $10^{-5}$ (1 in 100,000; ICRP [25].

Our results showed that activity concentrations of naturally occurring radionuclides, especially those of ${ }^{210} \mathrm{Po}$ and ${ }^{40} \mathrm{~K}$, were much higher than those of other natural and anthropogenic radionuclides. Among these, ${ }^{137} \mathrm{Cs}$ concentration was low and make only a small contribution (1\%) to the total radiation dose to biota and thus to human consumers of seafood. Fishes contained radionuclides, especially ${ }^{210} \mathrm{Po}$, in concentrations roughly similar to those found in coastal organisms of the same taxa. ${ }^{210} \mathrm{Po}$ concentrations seem to be dependent upon a food chain transfer of this radionuclide, so it seems that the ${ }^{210}$ Po concentration levels were more related to the trophic level of the organisms than the ocean depth at which they live. More data are needed on natural and artificial radionuclides in abyssal biota. The internal radiation doses received by marine biota and human beings seemed to be driven mainly by ${ }^{210} \mathrm{Po}$ and ${ }^{40} \mathrm{~K}$ and it appears unlikely that the benthic fishes are exposed to a radiation dose regime different from those fishes in pelagic environment. The estimated CED and lifetime risk were also found negligible and the species are considered safe for consumption.

\section{Acknowledgments}

The authors would like to express their thanks to the Board of Research in Nuclear Sciences (BRNS), Department of Atomic Energy (DAE), Government of India for providing financial assistance for this study (Sanc. No. 2004/36/16BRNS).

\section{References}

[1] Jensen H. H. Pollut. Bull. 53 (2006), 591-598.

[2] Ababouch L. Mar. Pollut. Bullet. 53 (2006) 561-568.

[3] Aarkrog A., Baxter M.S., Battercourt A.O., Bojanowski R., Bologa A., Charmasson S., Cunha I., Delfanti R., Duran E., Holm E., Jeffree R., Livingston H.D., Mahapanayawong S., Nies H., Osvath I., Pingyu Li., Povinec P.P., Sanchez A., Smith J.N. and D.J. Swift, J. Environ. Radioactivity, 34 (1997) 69-90.

[4] Khan M.F., Raj Y.L., Ross E.M. and S.G. Wesley. Inter. J. Low Radiat. 4 (2007), 217-231.

[5] James P.S.B.R. The Indian fisheries sector at the threshold of sixty momentous years of independence-in retrospect and prospect. In: Mohan Joseph Modayil \& Pillai, N.G.K (Eds.). Status and Perspectives in Marine Fisheries Research in India. Central Marine Fisheries Research Institute (CMFRI, 2007), Kochi, India, pp. 15-46.

[6] Khan M.F. and S.G. Wesley. J. Radioanal. Nucl. Chem. 285 (2010) 741-747.

[7] Khan M.F. and S.G. Wesley. Environ. Monit. Assess. 175 (2011) 623-632

[8] Vesterbacka P. and T.K. Ikaheimonen. Analytica Chemica Acta 545 (2005) 252-261.

[9] Alam M.N., Chowdhury M. I., Kamal M., Ghose S., Matin A. K. M. A. and G. S. M. Ferdousi. J. Environ. Radioactivity 47(1999) 201-212.

[10] Lazorenko G.E., Polikarpov G.G. and A. R. Boltachev. Russian J. Marine Biol. 28 (2002) 52-56.

[11] Carvalho F.P. Health Physics 69 (1995) 469-480.

[12] Carvalho F.P. and J. M. Oliveira. Radioactivity in marine organisms from Northeast Atlantic Ocean. In The Natural Radiation Environment (NRE VIII, 2008), Ed. by A. S. Paschoa, and F. Steinhaeusler. AIP Conference Proceedings, 1034. American Institute of Physics, Melville, New York, pp. 387-392.

[13] RIFE-13. Radioactivity in Food and Environment, 2007. Environment Agency, Food Standards Agency Northern Ireland Environment Agency, and Scottish Environment Protection Agency. CEFAS, 2008, UK. 
[14] NRPA. Radioactivity in the Marine Environment 2007. Results from the Norwegian National Monitoring Programme (RAME). StrålevernRapport 2009: 15. Norwegian Radiation Protection Authority, Østerås.

[15] International Atomic Energy Agency (IAEA). Assessment of doses to the public from ingested radionuclides. Safety report series No. 4, 1996, IAEA, Vienna.

[16] Khan M.F. and S.G. Wesley. Mar. Pollut. Bullet. 62 (2011) 399-404.

[17] Carvalho F.P. and S.W. Fowler. Mar. Ecol. Prog. Ser. 102 (1993) 125-133.

[18] Carvalho F.P. and S.W. Fowler. Mar. Ecol. Prog. Ser. 103 (1994) 251-264.

[19] Durand J.P., Carvalho F.P., Goudard F., Pieri, J., Fowler, S.W. and O. Cotret. Mar. Ecol. Prog. Ser. 177 (1999) 189-196.

[20] Cherry R.D. and M. Heyraud. Science 218 (1982) 54-56.

[21] Godoy J.M., Oliveira M.S., Almeida C.E.B., Carvalho Z.L., Silva E.R., Fernandes F.C., Pitanga F.L. and O.M. Danelon. J. Environ. Radioactivity, 99 (2008) 631-640.

[22] Khan M.F. and S.G. Wesley. Radiat. Prot. Dosim. 2010 (published online doi:10.1093/rpd/ncq447).

[23] USEPA. U.S. Environmental Protection Agency. Estimating radiogenic cancer risks. Federal Guidance Report 1994, EPA-402-R-93-076, Washington, DC.

[24] Khan M.F., Benjamin J. and S.G. Wesley. Toxicol. Environ. Chem. 93 (2011) 549-564.

[25] ICRP. International Commission on Radiological Protection. Recommendations of the international commission on radiological protection. ICRP Publication 60, Oxford, UK: Pergamon Press, 1991. 